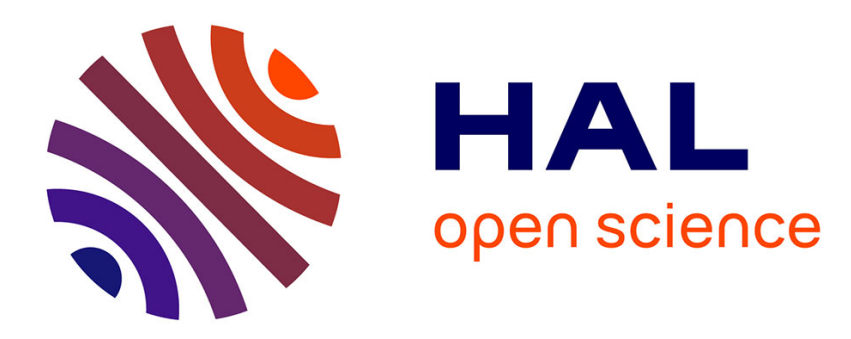

\title{
Boundary layer ozone pollution caused by future aircraft emissions
}

\author{
Didier Hauglustaine, Brigitte Koffi
}

\section{To cite this version:}

Didier Hauglustaine, Brigitte Koffi. Boundary layer ozone pollution caused by future aircraft emissions. Geophysical Research Letters, 2012, 39 (13), pp.n/a-n/a. 10.1029/2012GL052008 . hal03205614

\section{HAL Id: hal-03205614 \\ https://hal.science/hal-03205614}

Submitted on 26 Apr 2021

HAL is a multi-disciplinary open access archive for the deposit and dissemination of scientific research documents, whether they are published or not. The documents may come from teaching and research institutions in France or abroad, or from public or private research centers.
L'archive ouverte pluridisciplinaire HAL, est destinée au dépôt et à la diffusion de documents scientifiques de niveau recherche, publiés ou non, émanant des établissements d'enseignement et de recherche français ou étrangers, des laboratoires publics ou privés. 


\title{
Boundary layer ozone pollution caused by future aircraft emissions
}

\author{
Didier A. Hauglustaine ${ }^{1,2}$ and Brigitte Koffi ${ }^{1}$ \\ Received 12 April 2012; revised 6 June 2012; accepted 10 June 2012; published 12 July 2012.
}

[1] In addition to their impact on the radiative forcing of climate and on the composition of the upper-troposphere and lower-stratosphere region, global aircraft $\mathrm{NO}_{\mathrm{x}}$ emissions are found to contribute significantly to transport emission induced future ozone air pollution in Europe and in the United States. Based on various projections of 2050 emissions of short-lived pollutants by the three major transport sectors (i.e., road transportation, shipping, and aircraft), we show that aircraft $\mathrm{NO}_{\mathrm{x}}$ exhaust contribute by $30-40 \%$ to the summertime 8 h-average daily maximum surface ozone increase due to transport emissions in Europe and in the United States. Depending on the future scenario, over these two regions, an annual mean contribution of aircraft emissions of $25-48 \%$ to the boundary layer ozone burden increase associated with transport emissions in 2050 is simulated. Shipping emissions also represent a significant, and often dominant, contribution to future boundary layer ozone change due to transport emissions over land downwind of maritime corridors in the range $32-60 \%$ depending on the emission scenario. In the context of tighter emission standards for road transport in the future, these results indicate that aircraft and shipping emissions deserve consideration as a mean to improve air quality and reduce ozone pollution episodes. Citation: Hauglustaine, D. A., and B. Koffi (2012), Boundary layer ozone pollution caused by future aircraft emissions, Geophys. Res. Lett., 39, L13808, doi:10.1029/ 2012GL052008.

\section{Introduction}

[2] The environmental impact of the global subsonic aircraft fleet emissions is often considered through its contribution to the radiative forcing of climate associated with changes in the atmospheric distribution of radiatively active agents such as long-lived greenhouse gases (e.g., $\mathrm{CO}_{2}$, $\left.\mathrm{CH}_{4}\right)$, soot and sulfate particles, ozone $\left(\mathrm{O}_{3}\right)$, contrails, and induced cirrus. Aviation currently contributes a small but significant radiative forcing of climate estimated to be $78 \mathrm{~mW} / \mathrm{m}^{2}$ in 2005 or about $5 \%$ of the total anthropogenic forcing since the pre-industrial [Lee et al., 2009]. However, aircraft traffic increased by $5.3 \%$ /yr over the 2000-2007 period and projections suggest a growth rate of the order of $4.5-6 \% / y r$ over the next 20 years, so that aviation con-

\footnotetext{
${ }^{1}$ Now at Laboratoire des Sciences du Climat et de l'Environnement, UMR 8212, CEA-CNRS-UVSQ, Gif-sur-Yvette, France.

${ }^{2}$ Laboratoire Image Ville Environnement, ERL 7230, CNRS, Université de Strasbourg, Strasbourg, France.

Corresponding author: D. A. Hauglustaine, Laboratoire des Sciences du Climat et de l'Environnement, UMR 8212, CEA-CNRS-UVSQ, L'Orme des Merisiers, Bât. 712, F-91191 Gif-sur-Yvette CEDEX, France. (didier.hauglustaine@1sce.ipsl.fr)

(C)2012. American Geophysical Union. All Rights Reserved. 0094-8276/12/2012GL052008
}

tribution to the climate forcing would increase by a factor of 3-4 by 2050 [Lee et al., 2009].

[3] Nitrogen oxides $\left(\mathrm{NO}_{\mathrm{x}}\right)$ emissions from aircraft exert indirect climate forcings through changes in the distribution of $\mathrm{O}_{3}$, a radiatively active species, and through alteration of the methane lifetime in the atmosphere arising from the impact of ozone changes on the abundance of the hydroxyl radical OH [e.g., Johnson et al., 1992; Hauglustaine et al., 1994; Stevenson and Derwent, 2009; Holmes et al., 2011]. The impact of aircraft (and other traffic sectors) $\mathrm{NO}_{\mathrm{x}}(=\mathrm{NO}+$ $\mathrm{NO}_{2}$ ) emissions on the current and future global $\mathrm{O}_{3}$ distribution was recently assessed by Hoor et al. [2009], Koffi et al. [2010], and Hodnebrog et al. [2011] based on updated emission inventories. These studies confirm that presentday in-situ $\mathrm{NO}_{\mathrm{x}}$ aircraft emissions are on average 4-5 times more efficient to affect the global ozone burden than surface emissions from road transport for instance. Holmes et al. [2011] have identified processes that control background $\mathrm{NO}_{\mathrm{x}}$ in the free troposphere such as convection, lightning and surface $\mathrm{NO}_{\mathrm{x}}$ emissions as the likely cause of the spread in those model results. Despite this high sensitivity of ozone to aircraft $\mathrm{NO}_{\mathrm{x}}$, Fuglestvedt et al. [2010], Myhre et al. [2011], Hodnebrog et al. [2011], and Holmes et al. [2011] calculate that the radiative forcing of aircraft $\mathrm{NO}_{\mathrm{x}}$ is only a small contribution to the total aviation forcing, mainly due to compensating effects of the positive ozone and negative methane forcings.

[4] In the future, road transport emissions are expected to stagnate and even decrease due to tighter vehicle emission standards aiming at improving air quality [Uherek et al., 2010; Shindell et al., 2011]. Things are more complex in the case of aircraft and shipping emissions for which emission standards are set by the International Civil Aviation Organization (ICAO) and the International Maritime Organization (IMO). However, these emissions are not necessarily monitored and no national or international regulations are applied or are only starting to enter into force in the United States and European Union. In addition, for these sectors, low- $\mathrm{NO}_{\mathrm{x}}$ technology or carburant will also take more time to implement as the lifetime of carriers is longer. As a result, the relative contribution of aircraft and shipping emissions on atmospheric composition and climate is expected to increase compared to road transportation. This feature has been recently confirmed at a 2025-2050 timeframe depending on the future emission scenario from the IPCC SRES storylines by Hoor et al. [2009], Koffi et al. [2010], Hodnebrog et al. [2011], and Olivié et al. [2012].

[5] In this context, even if the radiative forcing of aircraft $\mathrm{NO}_{\mathrm{x}}$ is very likely to remain small in the future, another associated environmental impact could become a concern. Several studies have assessed the impact of aircraft emissions on local air quality, generally around airports [Unal et al., 2005; Hu et al., 2009; Woody et al., 2011]. In these studies, aircraft emissions were restricted to landing and 
takeoff cycles and only accounted for emissions below $3 \mathrm{~km}$. This limitation neglects the large-scale redistribution of aircraft emissions on atmospheric composition. It is unlikely that extra-tropical cruise-altitude aircraft emissions can affect surface air quality via dynamical transport and mixing alone [Whitt et al., 2011]. However, even if more than $60 \%$ of the global aircraft $\mathrm{NO}_{\mathrm{x}}$ emissions are found at cruisealtitude between 10 and $12 \mathrm{~km}$, a significant fraction of the emissions is emitted in the lower troposphere (about $25 \%$ below $5 \mathrm{~km}$ ) [Gardner et al., 1997].

[6] Air quality is to a large extent controlled by on-road passenger and freight transport emissions in cities and large urban centers. In the perspective of decreasing future road transport emissions as a result of more stringent vehicleemission standards, we show that future aircraft and shipping emissions also deserve consideration as a mean to improve air quality and ozone pollution episodes.

\section{Methods}

[7] We use the LMDz-INCA global chemistry-climate model which consists of the INCA3.0 (INteraction with Chemistry and Aerosols) model including a state-of-the-art $\mathrm{CH}_{4}-\mathrm{NO}_{\mathrm{x}}-\mathrm{CO}-\mathrm{NMHC}-\mathrm{O}_{3}$ tropospheric photochemistry [Hauglustaine et al., 2004; Folberth et al., 2006] coupled to the LMDz4.0 (Laboratoire de Météorologie Dynamique) General Circulation Model [Hourdin et al., 2006]. The model has 19 hybrid vertical levels extending up to $4 \mathrm{hPa}$, and a horizontal resolution of $2.5^{\circ}$ in latitude and $3.75^{\circ}$ in longitude. This version of the model has been extensively compared to observations in the lower-troposphere [e.g., Hauglustaine et al., 2004; Folberth et al., 2006; Szopa et al., 2007; Fiore et al., 2009; Reidmiller et al., 2009], and in the upper-troposphere at aircraft flight altitudes [e.g., Brunner et al., 2005; Dufour et al., 2007; Elias et al., 2011]. In the framework of the European Union project QUANTIFY (Quantifying the Climate Impact of Global and European Transport Systems), Schnadt-Poberaj et al. [2010] have performed a detailed evaluation of various models against the MOZAIC $\mathrm{O}_{3}$ and $\mathrm{CO}$ profiles at largely frequented airports. Based on this evaluation, typical relative biases for ozone exhibit a positive value of the order of up to $40 \%$ in winter and $10-30 \%$ in summer at the altitude range of 850 $500 \mathrm{hPa}$. We use the same modeling set-up as the one described by Koffi et al. [2010] to investigate the impact of traffic emissions on global atmospheric composition in the framework of QUANTIFY. In particular, since we focus on the impact of emission changes on atmospheric composition, all simulations are performed using the 2002-2003 meteorology with 2002 considered as a spin-up. The winds predicted by the LMDz GCM are therefore nudged towards the 6-hourly ECMWF fields over the whole model domain. Koffi et al. [2010] showed that the 2050 climate change does not significantly affect the transport emission-induced ozone perturbation. For instance the impact of transport emissions on global $\mathrm{OH}$ or the tropospheric $\mathrm{O}_{3}$ burden is affected by less than $2 \%$ when the 2050 climate is considered. The impact of traffic emissions on global tropospheric $\mathrm{O}_{3}, \mathrm{OH}$ and on the $\mathrm{O}_{3}$ and $\mathrm{CH}_{4}$ radiative forcings of climate as simulated for present-day and future conditions with LMDzINCA are generally consistent with other models as illustrated by the intercomparison results of Hoor et al. [2009], Hodnebrog et al. [2011], and Myhre et al. [2011].
[8] As described in Koffi et al. [2010], Hodnebrog et al. [2011], and Myhre et al. [2011], the traffic emissions of $\mathrm{NO}_{\mathrm{x}}, \mathrm{CO}$ and $\mathrm{NMHC}$ from the road, shipping and aircraft sectors used in this study are provided for the year 2000 and 2050 by QUANTIFY (http://www.ip-quantify.eu). The simulations are performed for one pessimistic (A1B) and one optimistic (B1) SRES scenarios [Nakicenovic and Swart, 2000]. In the case of aircraft emissions, in addition to the $\mathrm{A} 1 \mathrm{~B}$ and $\mathrm{B} 1$ scenarios, a possible mitigation scenario (B1 ACARE) prepared according to the Advisory Council for Aeronautical Research in Europe recommendations is also considered accounting for increased fuel efficiency through additional technological improvements to the aircraft [Owen et al., 2010; Hodnebrog et al., 2011]. The present and future shipping emissions are based on Endresen et al. [2007]. Road traffic emissions are based on Borken et al. [2007] and documented by Uherek et al. [2010]. The resulting present-day (2000) and future (2050) global traffic emissions used in this study are summarized in Table S1 in the auxiliary material. ${ }^{1}$ All surface emissions are injected in the lowest model level. In the case of aircraft, emissions are vertically interpolated from their original altitude grid to the time-varying model pressure levels at each time-step.

[9] The impact of total or individual traffic emissions on the atmospheric composition is simulated adopting a perturbation approach. For each sector the global emissions are reduced by a small amount (i.e., 5\%) to derive the sensitivity of the atmospheric composition to the considered sector. The full perturbation is then determined based on the calculated sensitivity and scaled up to the $100 \%$ emissions. This method is described by Grewe et al. [2010] and has been used in Hoor et al. [2009], Koffi et al. [2010], Myhre et al. [2011], and Hodnebrog et al. [2011]. The small perturbation approach should minimize non-linearity in atmospheric chemistry which would occur by setting the respective emission to zero. As discussed by Koffi et al. [2010], regional differences are expected in the resulting perturbations, in particular in the boundary layer at high $\mathrm{NO}_{\mathrm{x}}$ concentrations.

\section{Results}

[10] Before the impact of aircraft emissions on air pollution ozone is presented, we summarize the key findings of the LMDz-INCA model simulations in terms of global perturbations. For present-day conditions, we calculate a normalized tropospheric ozone change (ozone change below about $100 \mathrm{hPa}$ (i.e., model level 14) per $\mathrm{NO}_{\mathrm{x}}$ emitted, in mole $\mathrm{O}_{3}$ per mole of $\mathrm{N}$ ) of 1.48 for aircraft, 0.41 for shipping, and 0.34 for road transport emissions. This indicates that aircraft $\mathrm{NO}_{\mathrm{x}}$ are 4.35 times more efficient to produce ozone than surface emissions from road transport. In 2050, at higher aircraft emissions for the A1B scenario, this efficiency is slightly reduced. However, aircraft $\mathrm{NO}_{\mathrm{x}}$ remain 3.4 times more efficient to produce ozone than road transportation. At lower background $\mathrm{NO}_{\mathrm{x}}$ conditions, aircraft are 4.0 and 4.4 times more efficient to produce ozone than road emissions for the B1 and B1 ACARE scenarios. Similarly, in 2050, aircraft $\mathrm{NO}_{\mathrm{x}}$ are 3.5 times more efficient to produce ozone than ship $\mathrm{NO}_{\mathrm{x}}$ emissions under scenarios $\mathrm{A} 1 \mathrm{~B}$ and $\mathrm{B} 1$

\footnotetext{
${ }^{1}$ Auxiliary materials are available in the HTML. doi:10.1029/ 2012GL052008.
} 
(3.9 times for B1 ACARE). The methane base lifetime ( $8.5 \mathrm{yr}$ ) decreases by $1 \%$ due to aircraft emissions in 2000 and by $3.4 \%, 1.3 \%$ and $0.9 \%$ in 2050 under scenarios $\mathrm{A} 1 \mathrm{~B}$, $\mathrm{B} 1$ and B1 ACARE, respectively. Based on these perturbations of the atmospheric composition and the LMDz GCM radiative transfer model [Fouquart and Bonel, 1980; Morcrette, 1991], we derive radiative forcings (positive tropospheric ozone forcing plus methane negative forcing) due to aircraft $\mathrm{NO}_{\mathrm{x}}$ of $0.3 \mathrm{~mW} / \mathrm{m}^{2}$ in 2000 and $6.3,1.1$ and $0.9 \mathrm{~mW} / \mathrm{m}^{2}$ in 2050 for scenarios $\mathrm{A} 1 \mathrm{~B}, \mathrm{~B} 1$ and B1 ACARE, respectively. The methane radiative forcing includes the feedback of $\mathrm{CH}_{4}$ on its own lifetime and the indirect $\mathrm{H}_{2} \mathrm{O}$ and $\mathrm{O}_{3}$ contributions but the time history of $\mathrm{NO}_{x}$ emissions is not included [Grewe and Stenke, 2008; Myhre et al., 2011]. Note that if we account for the historical trend in $\mathrm{NO}_{\mathrm{x}}$ emissions, we derive $\mathrm{CH}_{4}$ forcings in 2000 of -9.7 , -37.1 and $-18.6 \mathrm{~mW} / \mathrm{m}^{2}$ for aircraft, shipping and road transport emissions, respectively. In this case, the presentday total forcings for these three transport sectors are 5.5, -16.9 , and $18.5 \mathrm{~mW} / \mathrm{m}^{2}$. These values are consistent with the calculations by Myhre et al. [2011] under the same assumptions. More generally, these global perturbations of the atmospheric composition by the three transport sectors which are described in more details by Koffi et al. [2010] and summarized in Table S1 in the auxiliary material are in agreement with other state-of-the-art global models and give confidence to the LMDz-INCA model results [Hoor et al., 2009; Hodnebrog et al., 2011; Myhre et al., 2011].

[11] We now turn our attention to the transport sector induced perturbation of boundary layer ozone simulated for the year 2050. Figure 1 shows the response of surface ozone in 2050 to the emissions from the three transport sectors (aircraft, shipping, road) according to the A1B scenario. The maximum daily 8-hour averaged (MDA8) ozone change due to transport emissions and averaged over the June-JulyAugust period is shown. The relative contribution of each transport sector to this ozone change is also provided. Over Europe, ozone increases by up to $4-5$ ppbv. In Southern Europe (e.g., Italy, Spain), but also in Scandinavia, transport of boundary layer shipping $\mathrm{NO}_{\mathrm{x}}$ to the continents contributes by $50-70 \%$ to the ozone change. This is also the case in coastal areas (e.g., Western France). However, over most of Europe, aircraft emissions contribute by $30-40 \%$ to the transport emission induced ozone increase. A maximum contribution of aircraft of $2.5 \mathrm{ppbv}$ (see auxiliary material) is calculated over central Europe. Over the United States, ozone increases by 3-4 ppbv due to transport emissions. Aircraft emissions contribute by $30-40 \%$ to this ozone change with a maximum reaching 2 ppbv over the West and East coasts. Over the ocean (i.e., Northern Pacific, Northern Atlantic) and marine areas (e.g., the Mediterranean, Baltic, Arabian Sea) future shipping emissions are responsible for a general 5 ppbv increase in ozone. This feature extends to coastal areas downwind of shipping routes. We note however, an ozone titration over the North Sea due to high background $\mathrm{NO}_{\mathrm{x}}$ concentrations in this region. By definition of the small perturbation methodology used here (see Section 2), large differences are precisely expected in this region characterized by strong non-linearities in the chemical regime. The impact on the calculated ozone change of a full decline in emission in comparison to the small-perturbation approach is in general lower than $+10 \%$. In the North Sea region, this difference between the two methods reaches 40
$60 \%$ for shipping emissions. In this area the total perturbation approach would further increase the relative contribution of shipping to the ozone change by the transport sector.

[12] Over land, we find that aircraft generally contributes by more than $30 \%$ to the MDA 8 surface ozone increase in 2050. Aircraft $\mathrm{NO}_{\mathrm{x}}$ emissions also affect surface ozone peak values during summer. Over central Europe and the Western United-States, the maximum impact of transport emissions on the 90th percentile ozone mixing ratio reaches 3-3.5 ppbv. This maximum increase in ozone peak values is attributed to aircraft $\mathrm{NO}_{\mathrm{x}}$ emissions (see auxiliary material).

[13] Figure 2 shows the relative contribution of each transport mode to the integrated boundary layer ozone increase in 2050 over Europe and the United States for each season. For the A1B scenario, aircraft emissions contribute for $45 \%$ to the ozone increase due to transport emissions in Europe on an annual mean. Road transportation contributes for $15 \%$ to this perturbation and shipping for the remaining $40 \%$. The contribution of aircraft ranges from $39 \%$ in summer to $60 \%$ during winter. Over the United States, the annual contribution of aircraft emissions to the ozone increase reaches $48 \%$ while road transportation contributes for $15 \%$ and shipping for $37 \%$. The contribution of aircraft to the boundary layer ozone increase ranges from $48 \%$ in summer to $53 \%$ in winter with a somewhat lesser influence from shipping inland than in the European domain as defined here. With a global aircraft $\mathrm{NO}_{\mathrm{x}}$ emission of 3.3 TgN/yr, scenario A1B appears as a pessimistic scenario in terms of aircraft and shipping emission increase and could be seen as an upper limit in terms of relative aircraft contribution to surface ozone increase. The future contribution of aircraft $\mathrm{NO}_{\mathrm{x}}$ to ozone increase in Europe and in the United States has also been investigated under scenario B1 (see auxiliary material) and under the mitigation scenario B1 ACARE (Figure 2). In the case of the B1 scenario, aircraft contribute by $32 \%$ and $36 \%$ to the 2050 ozone increase in Europe and in the US, respectively. The contribution of road transport remains below $10 \%$ in both regions and shipping contributes by more than $50 \%$ to the 2050 perturbation. The B1 ACARE scenario can be seen as a lower limit of aircraft future emissions with a global emission of only $0.7 \mathrm{TgN} / \mathrm{yr}$, a value even lower than the actual $0.85 \mathrm{TgN} / \mathrm{yr}$. For the B1 ACARE future scenario, the annual contribution of aircraft to the transport sector surface ozone increase in Europe amounts to $25 \%$. Road transport contributes for less than $8 \%$ and shipping for $67 \%$ to the boundary layer ozone increase. Similar values are derived for the United States with a $28 \%$ contribution for aircraft in annual average with little seasonal variation. Again, the contribution of road traffic remains lower than $10 \%$ and an important contribution of shipping of more than $60 \%$ is calculated. Based on these simulations it appears in all cases, and even for the aircraft emission mitigation scenario B1 ACARE, that aircraft play a significant contribution of $25-47 \%$ to the boundary layer ozone increase in the US and in Europe by 2050, with road transport contributing for only $10-15 \%$. Shipping emissions and their redistribution to the continents mostly downstream of marine shipping routes also appear as a key player responsible for up to $60 \%$ to the ozone pollution increase.

[14] A new set of scenarios for the future evolution of atmospheric composition known as the Representative Concentration Pathways (RCPs) has been adopted by the scientific community [Moss et al., 2010]. The RCPs are 
meant to replace the former SRES scenarios [Nakicenovic and Swart, 2000]. Deriving the emissions of reactive species for pollution studies was not the driving force behind these scenarios designed for climate simulations. The
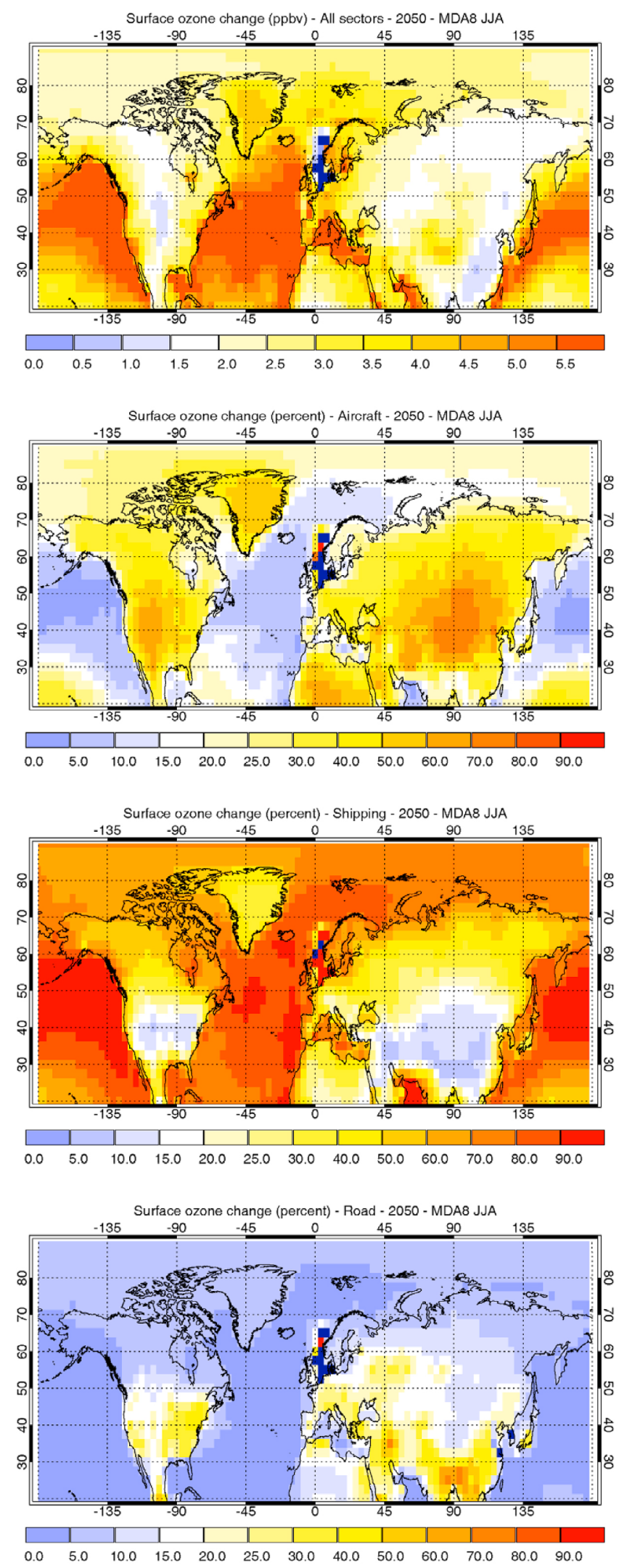

transport emissions used in this study and based on the QUANTIFY project probably rely on more detailed estimates of future emission control measures and air quality legislation for short-lived species. Global aircraft $\mathrm{NO}_{\mathrm{x}}$ emissions in 2050 range from $1.2 \mathrm{TgN} / \mathrm{yr}$ for the RCP2.6 to $2 \mathrm{TgN} / \mathrm{yr}$ for the RCP8.5. These values lie between the A1B and $\mathrm{B} 1$ emissions considered in this study for this sector. According to the RCP storylines, shipping emissions in 2050 range from $3.1 \mathrm{TgN} / \mathrm{yr}$ to $6.7 \mathrm{TgN} / \mathrm{yr}$, values also in line with the emissions used here with a lower estimate in the case of the RCP6.0. The major difference between the RCPs and the emissions from QUANTIFY arises from global road transport emissions in 2050 which range from $0.8 \mathrm{TgN} / \mathrm{yr}$ to $8.5 \mathrm{TgN} / \mathrm{yr}$ in the RCPs. Except for the RCP2.6, these values are significantly larger than the emissions used in this study even for the pessimistic A1B scenario. These higher road traffic emissions for three of the RCP scenarios are driven by increased emissions over Asia-India and over Africa. In OECD (Organisation for Economic Co-operation and Development) countries, the decrease of road traffic emissions in the RCPs by 2050 is in line with the one seen in the emissions used in this study. Since we focus this work on surface ozone in Europe and in the United States, these higher emissions in Asia and India derived by the RCPs should not significantly affect our conclusions regarding the annual mean contribution of aircraft emissions to ozone increase in these regions. However, during specific period of the year, transport of Asian surface emissions to the United States could contribute to the increase in MDA8 surface ozone [Lin et al., 2012]. There is a high degree of uncertainty in future Asian surface emissions and this feature should be addressed in further details with emissions scenarios integrating detailed emission regulations for air quality and in particular for road transport within the RCP storylines.

\section{Conclusion}

[15] In this study, a global three-dimensional chemistryclimate model has been used to assess the contribution of future aircraft $\mathrm{NO}_{\mathrm{x}}$ emissions to ozone air pollution relative to road transport and shipping emissions. Different scenarios have been adopted in order to represent 2050 emissions by the various transport modes along the IPCC SRES storylines. A mitigation scenario has also been considered for future aircraft emissions. Depending on the future scenario, it is found that low-altitude aircraft emissions contribute by $25-48 \%$ to the annual mean boundary layer ozone increase due to transport emissions over Europe and the United States. In these regions, road transport has an impact on the surface ozone levels of only $10-15 \%$. Aircraft $\mathrm{NO}_{\mathrm{x}}$ emissions have the potential to affect not only the ozone burden

\footnotetext{
Figure 1. Maximum daily 8h-average (MDA8) change in surface ozone in June-July-August 2050 associated with the total three transport sector future emissions under A1B scenario (ppbv). Relative contribution (\%) of aircraft, shipping and road emissions to this surface ozone change due to transport emissions. The MDA8 surface ozone mixing ratio is determined based on hourly output model data at each grid-cell, using a $8 \mathrm{~h}$ running mean in order to determine each day the corresponding MDA8. These daily maxima are then averaged over the June-July-August period.
} 

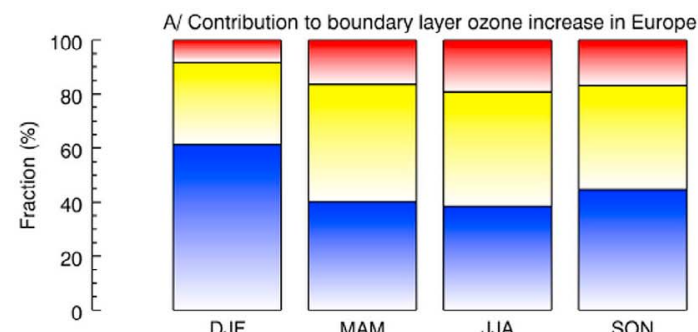

B/ Contribution to boundary layer ozone increase in the US
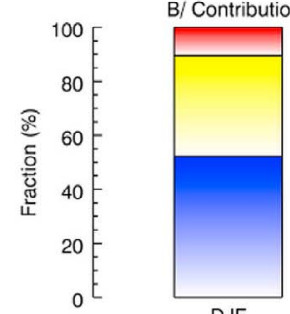

DJF
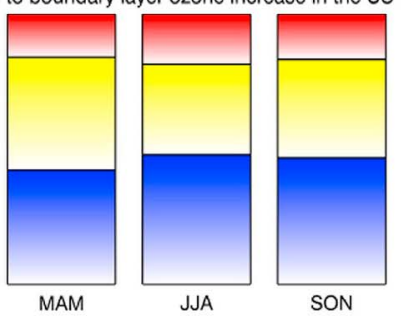
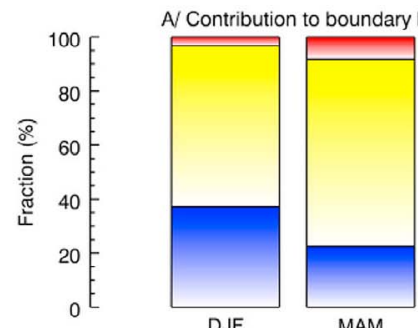

DJF

MAM

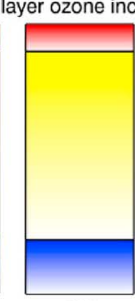

JJA
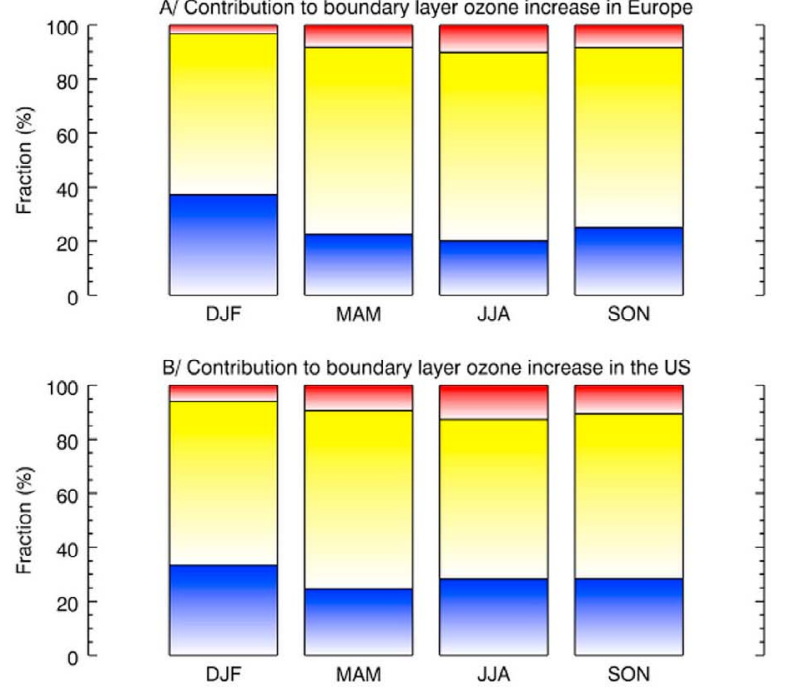

Figure 2. Relative contribution (\%) of aircraft (blue), shipping (yellow), and road (red) emissions to boundary layer ozone increase due to transport in Europe $\left(40^{\circ} \mathrm{N}-55^{\circ} \mathrm{N} ; 3.7^{\circ} \mathrm{W}-41.25^{\circ} \mathrm{E}\right)$ and in the United States $\left(30^{\circ} \mathrm{N}-50^{\circ} \mathrm{N} ; 120^{\circ} \mathrm{W}-78.75^{\circ} \mathrm{W}\right)$ in 2050 under (left) A1B and (right) B1 ACARE scenarios. The ozone change is integrated from the ground level to the pressure of $910 \mathrm{hPa}$ (lowest three model levels).

in the continental boundary layer but also the change in summertime 8-hour daily maximum surface $\mathrm{O}_{3}$ mixing ratio and even the ozone peak values (90th percentile ozone mixing ratios) in Europe and in the US. Our results show little sensitivity to future climate change. We find in particular that the impact of transport emissions on surface ozone over the US and Europe is affected by less than $10 \%$ by the warmer A1B 2050 climate.

[16] These results indicate that in the perspective of decreasing future road transport emissions as a result of more stringent vehicle-emission standards in the OECD countries, aircraft emissions deserve consideration as a mean to improve air quality and ozone pollution episodes in particular. It also appears that in absence of future stringent standards, shipping emissions will also play a significant, and often dominant, contribution to surface ozone increase due to transport emissions over Europe and the US due to ozone formation downwind of maritime corridors.

[17] While the state-of-the-art model used in this work is generally in line with other model results and compares well to observations, previous work has stressed the spread in the model results in particular in the case of ozone perturbation to aircraft emissions and its future evolution. In particular the results are sensitive to the vertical mixing of aircraft emissions. The use of a different deep convection scheme in LMDz-INCA for instance has a 10-30\% impact on the surface ozone change associated with aircraft emissions in summer. Future research should therefore conduct model intercomparisons and ensemble analysis on this potentially important topic for air quality. We also note that there is a high degree of uncertainty on the future evolution of road transport emissions, especially in China, South-East Asia and India, as revealed by the new RCP scenarios increasing traffic emissions in these regions. It is in particular crucial to account for future tighter emission standards for air quality in these countries before these scenarios can be used to refine the finding of this study relying on the SRES storylines.
[18] Acknowledgments. This work was funded by the European Union within the FP6 QUANTIFY project, under contract 003893. It was also supported by the 'Division des Programmes de l'Aviation Civile (DPAC)'. The emission inventories used in this work were provided by QUANTIFY partners: DNV (shipping), DLR (road traffic), MMU (aircraft), and JRC (other anthropogenic emissions). The computer time for these simulations has been provided by DSM-CCRT.

[19] The Editor and authors thank two anonymous reviewers for assisting in the evaluation of this paper.

\section{References}

Borken, J., H. Steller, T. Meretei, and F. Vanhove (2007), Global and country inventory of road transport passenger and freight transportation: Fuel consumption and emissions of air pollutants in year 2000, Transp. Res. Rec., 2011, 127-136, doi:10.3141/2011-14.

Brunner, D., et al. (2005), An evaluation of the performance of chemistry transport models. Part 2: Detailed comparison with two selected campaigns, Atmos. Chem. Phys., 5, 107-129, doi:10.5194/acp-5-107-2005.

Dufour, G., S. Szopa, D. A. Hauglustaine, C. D. Boone, C. P. Rinsland, and P. F. Bernath (2007), The influence of biogenic emissions on uppertropospheric methanol as revealed from space, Atmos. Chem. Phys., 7, 6119-6129, doi:10.5194/acp-7-6119-2007.

Elias, T., S. Szopa, A. Zahn, T. Schuck, C. Brenninkmeijer, D. Sprung, and F. Slemr (2011), Acetone variability in the upper troposphere: Analysis of CARIBIC observations and LMDz-INCA chemistry-climate model simulations, Atmos. Chem. Phys., 11, 8053-8074, doi:10.5194/acp-118053-2011.

Endresen, O., E. Sorgard, H. L. Behrens, P. O. Brett, and I. S. A. Isaksen (2007), A historical reconstruction of ships fuel consumption and emissions, J. Geophys. Res., 112, D12301, doi:10.1029/2006JD007630.

Fiore, A. M., et al. (2009), Multi-model estimates of intercontinental source-receptor relationships for ozone pollution, J. Geophys. Res., 114, D04301, doi:10.1029/2008JD010816.

Folberth, G. A., D. A. Hauglustaine, J. Lathière, and F. Brocheton (2006), Interactive chemistry in the Laboratoire de Météorologie Dynamique general circulation model : model description and impact analysis of biogenic hydrocarbons on tropospheric chemistry, Atmos. Chem. Phys., 6, 2273-2319, doi:10.5194/acp-6-2273-2006.

Fouquart, Y., and B. Bonel (1980), Computations of solar heating of the Earth's atmosphere: A new parameterization, Beitr. Phys. Atmos., 53, 35-62.

Fuglestvedt, J. S., K. P. Shine, J. Cook, T. Berntsen, D. S. Lee, A. Stenke, R. B. Skeie, G. J. M. Velders, and I. A. Waitz (2010), Assessment of transport impacts on climate and ozone: Metrics, Atmos. Environ., 44, 4648-4677, doi:10.1016/j.atmosenv.2009.04.044. 
Gardner, R. M., et al. (1997), The ANCAT/EC global inventory of NOx emissions from aircraft, Atmos. Environ., 31(12), 1751-1766, doi:10.1016/ S1352-2310(96)00328-7.

Grewe, V., and A. Stenke (2008), AirClim: An efficient tool for climate evaluation of aircraft technology, Atmos. Chem. Phys., 8, 4621-4639, doi:10.5194/acp-8-4621-2008.

Grewe, V., E. Tsati, and P. Hoor (2010), On the attribution of contributions of atmospheric trace gases to emissions in atmospheric model applications, Geosci. Model Dev., 3, 487-499, doi:10.5194/gmd-3-487-2010.

Hauglustaine, D. A., C. Granier, G. P. Brasseur, and G. Mégie (1994), Impact of present aircraft emissions of nitrogen oxides on tropospheric ozone and climate forcing, Geophys. Res. Lett., 21, 2031-2034, doi:10.1029/ 94GL01729.

Hauglustaine, D. A., F. Hourdin, S. Walters, L. Jourdain, M.-A. Filiberti, J.-F. Larmarque, and E. A. Holland (2004), Interactive chemistry in the Laboratoire de Météorologie Dynamique general circulation model: Description and background tropospheric chemistry evaluation, J. Geophys. Res., 109, D04314, doi:10.1029/2003JD003957.

Hodnebrog, O., et al. (2011), Future impact of non-land based traffic emissions on atmospheric ozone and $\mathrm{OH}-$ An optimistic scenario and a possible mitigation strategy, Atmos. Chem. Phys., 11, 11,293-11,317, doi:10.5194/acp11-11293-2011.

Holmes, C. D., Q. Tang, and M. Prather (2011), Uncertainties in climate assessment for the case of aviation NO, Proc. Natl. Acad. Sci. U. S. A., 108, 10,997-11,002, doi:10.1073/pnas.1101458108.

Hoor, P., et al. (2009), The impact of traffic emissions on atmospheric ozone and OH: Results from QUANTIFY, Atmos. Chem. Phys., 9, 3113-3136, doi:10.5194/acp-9-3113-2009.

Hourdin, F., et al. (2006), The LMDZ4 general circulation model: Climate performance and sensitivity to parametrized physics with emphasis on tropical convection, Clim. Dyn., 27, 787-813, doi:10.1007/s00382-0060158-0.

Hu, S., S. Fruin, K. Kozawa, S. Mara, A. M. Winer, and S. E. Paulson (2009), Aircraft emission impacts in a neighborhood adjacent to a general aviation airport in Southern California, Environ. Sci. Technol., 43(21), 8039-8045, doi:10.1021/es900975f.

Johnson, C., J. Henshaw, and G. McInnes (1992), Impact of aircraft and surface emissions of nitrogen oxides on tropospheric ozone and global warming, Nature, 355, 69-71, doi:10.1038/355069a0.

Koffi, B., S. Szopa, A. Cozic, D. Hauglustaine, and P. Van Velthoven (2010), Present and future impact of aircraft, road traffic and shipping emissions on global tropospheric ozone, Atmos. Chem. Phys., 10, 11,681-11,705, doi:10.5194/acp-10-11681-2010.

Lee, D. S., D. W. Fahey, P. M. Forster, P. J. Newton, R. C. N. Wit, L. L. Lim, B. Owen, and R. Sausen (2009), Aviation and global climate change in the 21st century, Atmos. Environ., 43, 3520-3537, doi:10.1016/j. atmosenv.2009.04.024

Lin, M., et al. (2012), Transport of Asian pollution into surface air over the western United States in spring, J. Geophys. Res., 117, D00V07, doi:10.1029/2011JD016961.
Morcrette, J.-J. (1991), Radiation and cloud radiative properties in the European Centre for Medium Range Weather Forecasts forecasting system, J. Geophys. Res., 96, 9121-9132, doi:10.1029/89JD01597.

Moss, R. H., et al. (2010), The next generation of scenarios for climate change research and assessment, Nature, 463, 747-756, doi:10.1038/ nature 08823 .

Myhre, G., et al. (2011), Radiative forcing due to changes in ozone and methane caused by the transport sector, Atmos. Environ., 45, 387-394, doi:10.1016/j.atmosenv.2010.10.001.

Nakicenovic, N., and R. Swart (Eds.) (2000), IPCC Special Report on Emissions Scenarios, Cambridge Univ. Press, Cambridge, U. K.

Olivié, D. J. L., et al. (2012), Modeling the climate impact of road transport, maritime shipping and aviation over the period 1860-2100 with an AOGCM, Atmos. Chem. Phys., 12, 1449-1480, doi:10.5194/acp-121449-2012.

Owen, B., D. S. Lee, and L. Lim (2010), Flying into the future: Aviation emissions scenarios to 2050, Environ. Sci. Technol., 44, 2255-2260, doi: $10.1021 /$ es $902530 \mathrm{z}$

Reidmiller, D. R., et al. (2009), The influence of foreign vs. North American emissions on surface ozone in the US, Atmos. Chem. Phys., 9, 5027-5042, doi:10.5194/acp-9-5027-2009.

Schnadt-Poberaj, C., et al. (2010), QUANTIFY model evaluation of global chemistry model: carbon monoxide, in Proceedings of the 2nd International Conference on Transport, Atmosphere and Climate, pp. 163-168, DLR Forschungsbericht, Cologne, Germany.

Shindell, D., G. Faluvegi, M. Walsh, S. C. Anenberg, R. Van Dingenen, N. Z. Muller, J. Austin, D. Koch, and G. Milly (2011), Climate, health, agricultural and economic impacts of tighter vehicle-emission standards, Nat. Clim. Change., 1, 59-66, doi:10.1038/nclimate1066.

Stevenson, D. S., and R. G. Derwent (2009), Does the location of aircraft nitrogen emissions affect their climate impact?, Geophys. Res. Lett., 36 , L17810, doi:10.1029/2009GL039422.

Szopa, S., D. A. Hauglustaine, and P. Ciais (2007), Relative contributions of biomass burning emissions and atmospheric transport to carbon monoxide interannual variability, Geophys. Res. Lett., 34, L18810, doi:10.1029/ 2007 GL030231.

Uherek, E., et al. (2010), Transport impacts on atmosphere and climate: Land transport, Atmos. Environ., 44, 4772-4816, doi:10.1016/j.atmosenv. 2010.01.002.

Unal, A., Y. Hu, M. Chang, M. Odman, and A. Russell (2005), Airport related emissions and impact on air quality: Application to the Atlanta International Airport, Atmos. Environ., 39, 5787-5798, doi:10.1016/j. atmosenv.2005.05.051.

Whitt, D. B., M. Z. Jacobson, J. T. Wilkerson, A. D. Naiman, and S. K. Lele (2011), Vertical mixing of commercial aviation emissions from cruise altitude to the surface, J. Geophys. Res., 116, D14109, doi:10.1029/ 2010JD015532.

Woody, M., B. H. Baek, Z. Adelman, M. Omary, Y. F. Lam, J. West, and S. Arunachalam (2011), An assessment of aviation's contribution to current and future fine particulate matter in the United States, Atmos. Environ., 45, 3424-3433, doi:10.1016/j.atmosenv.2011.03.041. 